\title{
Applying the CISG via the rules of private international law: Articles 1(1)(b) and 95 of the CISG - analysing CISG Advisory Council Opinion 15
}

Marlene Wethmar-Lemmer

BCom LLB LLM MA LLD

Associate Professor, College of Law, University of South Africa

\section{OPSOMMING}

Toepassing van die Weense Koopverdrag via die internasionale privaatreg: Artikels 1(1)(b) en 95 van die CISG - 'n analise van die CISG Advisory Council Opinie

Die Weense Koopverdrag (bekend onder die Engelse akroniem 'CISG') is 'n invloedryke internasionale verdrag wat tans vyf en tagtig lidstate verteenwoordigend van alle regstradisies het. Indien van toepassing, reguleer die verdrag die totstandkoming sowel as die regte en verpligtinge van die koper en verkoper tot ' $n$ internasionale koopkontrak vir roerende goedere. Ingevolge artikel 1(1) van die CISG is die verdrag van toepassing indien (a) die partye tot die koopkontrak van verskillende lidstate afkomstig is of (b) indien die reëls van die internasionale privaatreg lei tot die toepassing van die reg van 'n lidstaat. Artikel 95 van die CISG magtig 'n lidstaat om 'n voorbehoud te maak dat die betrokke lidstaat nie aan artikel 1(1)(b) gebonde is nie. Die voorbehoud het 'n beduidende invloed op die toepassingsgebied van die verdrag en die korrekte interpretasie van die bepaling is dus van groot belang vir howe in lidlande en nie-lidlande. Die interpretasie van die artikel 95-voorbehoud het al tot baie kontroversie en akademiese kommentaar aanleiding gegee. Onlangs het die CISG Advisory Council 'n opinie oor die interpretasie van die bepaling gepubliseer en daar word voorsien dat hierdie interpretasie heel invloedryk sal wees. In hierdie bydrae word die CISG Advisory Council se interpretasie van die impak van 'n artikel 95 - voorbehoud op die CISG se toepassingsgebied ontleed.

\section{Introduction}

The United Nations Convention on Contracts for the International Sale of Goods (CISG or the Convention) ${ }^{1}$ provides a set of uniform substantive law rules to govern the formation of international contracts for the sale of goods, as well as the rights and obligations of buyers and sellers. ${ }^{2}$

1 UN Doc A/CONF 97/18: 1489 UNTS. This Convention was adopted at a diplomatic conference of the United Nations held in Vienna during 1980 and entered into force on 1988-01-01; available from http://www. uncitral.org/pdf/english/texts/sales/cisg/V1056997-CISG-e-book.pdf (accessed 2015-07-15).

2 Art 4 of the CISG.

How to cite: Wethmar-Lemmer 'Applying the CISG via the rules of private international law: Articles 1(1)(b) and 95 of the CISG - analysing CISG Advisory Council Opinion 15' 2016 De Jure 58-73 http://dx.doi.org/10.17159/2225-7160/2016/v49n1a4 
According to article 1(1) of the CISG, the CISG 'applies to contracts of sale of goods between parties whose places of business are in different states (a) when the states are contracting states or (b) when the rules of private international law lead to the application of the law of a CISG contracting state'. 3

Given the large number of contracting states, representative of all legal traditions, as well as its important subject matter, the CISG is one of the most influential international conventions to date. The number of contracting states to the CISG has increased from 73 to 85 in the last five years. ${ }^{4}$ Even though South Africa is not a contracting state as yet, most of its largest trading partners are CISG contracting states ${ }^{5}$ and South Africa, therefore, should accede to the Convention as soon as possible. ${ }^{6}$ It would also ensure regional harmonisation of international sales law if all Southern African Development Country (SADC) states were to accede to the CISG. ${ }^{7}$ From a BRICS $^{8}$ perspective, China and Russia have been CISG contracting states from 1988 and 1991 respectively, and Brazil acceded in 2013. ${ }^{9}$ It would therefore promote international trade between BRICS states if India and South Africa would follow Brazil's recent example and accede to the CISG.

Article 95 of the CISG impacts upon the convention's scope of application and this provision's interpretation, therefore, is of paramount importance for correct application of the Convention. In light of the

3 See art 1(1) of the CISG concerning its scope of application. For an analysis of the scope of application from a South African vantage point, see Hugo 'The United Nations Convention on the International Sale of Goods: Its scope of application from a South African perspective' 1999 SA Merc LJ 1; Wethmar-Lemmer 'When could a South African court be expected to apply the CISG?' 2008 De Jure 419; and Wethmar-Lemmer 'The important role of private international law in harmonising international sales law' $2014 S A$ Merc LJ 93.

4 See the status document detailing all contracting states as well as their date of signature, accession or ratification of the Convention, available from http://www.uncitral.org/uncitral/en/uncitral_texts/sale_goods/1980CISG_sta tus.html (accessed 2016-07-19).

5 South Africa's largest trading partners are currently China, the United States and Germany - see http://www.southafricaweb.co.za/page/trade-and-indus try-south-africa (accessed 2015-07-15) in this regard. All three of South Africa's largest trading partners are CISG contracting states (as indicated on the status document).

6 Eiselen 'Adoption of the Vienna Convention for the International Sales of Goods (CISG) in South Africa' 1999 SALJ 323; Eiselen 'Adopting the Vienna Sales Convention: Reflections eight years down the line' 2007 SA Merc LJ 14.

7 Wethmar-Lemmer 2014 SA Merc LJ supra n 3 at 109.

8 BRICS is an acronym for five of the major emerging economies, namely Brazil, Russia, India, China and South Africa. For more information, access the BRICS Information Sharing and Exchanging Platform available from http://www.brics-info.org/ (accessed 2016-07-21).

9 UNCITRAL 'Status: United Nations Convention on Contracts for the International Sale of Goods' 2016 available from http://www.uncitral. org/uncitral/en/uncitral_texts/sale_goods/1980CISG_status.html (accessed 2016-07-19). 
almost worldwide accession to the CISG, courts in contracting and noncontracting states alike are regularly faced with questions concerning its application. South African courts and merchants should therefore pay heed to the correct interpretation of article 95 of the CISG.

Article 95 of the CISG provides that any 'state may declare at the time of the deposit of its instrument of ratification, acceptance, approval or accession that it will not be bound by subparagraph (1)(b) of article 1 of this Convention'. ${ }^{10}$ As referred to above, article 1(1)(b) contains one of the two alternative applicability criteria of the CISG and provides that it applies when the rules of private international law refer to the law of a contracting state.

Even though the meaning of article 95 seems relatively clear at first glance, it has given rise to much controversy and its interpretation and application has generated considerable scholarly debate. ${ }^{11}$ Recently, the CISG Advisory Council ${ }^{12}$ published an opinion on its interpretation. ${ }^{13}$

This CISG AC Opinion will be analysed in this contribution. Since article 95 was analysed in detail by the present author in a previous edition of this journal, ${ }^{14}$ its background and history will not be repeated. This article will engage with the Advisory Council's interpretation of this provision and focus on a remaining contentious matter, namely, the correct interpretation and application of the proper law of a contract.

\section{Use of Terminology Explained}

The terms 'reservation' and 'declaration' are used interchangeably in this contribution to denote a 'unilateral statement, however phrased or named, made by a State, when signing, ratifying, accepting, approving or acceding to a treaty, whereby it purports to exclude or to modify the

10 See the text of the Convention. To date, six states have availed themselves of the option of making an article 95 reservation. Of importance for South Africa, is the fact that these states include China, Russia and the United States. See the CISG status document in this regard.

11 Ferrari Contracts for the International Sale of Goods. Applicability and Applications of the 1980 United Nations Sales Convention (2012) 87 states that "there is no agreement on the extent to which the article 95 reservation narrows down the CISG's applicability'.

12 See par 3 below.

13 CISG AC Opinion No 15 'Reservations under Articles 95 and 96 CISG' Rapporteur: Schroeter (University of Mannheim, Germany); adopted by the CISG AC following its $18^{\text {th }}$ meeting in Beijing, China on 21 and 22 October 2013. The opinion is available from http://www.cisgac.com/cisgac-opinionno15/ (accessed 2016-07-21).

14 Wethmar-Lemmer 'The impact of the article 95 reservation on the sphere of application of the United Nations Convention on Contracts for the International sale of Goods (CISG)' 2010 De Jure supra n 14 at 362. 
legal effect of certain provisions of the treaty in their application to that State'. ${ }^{15}$ For purposes of this article, 'reservation state' or 'reservation contracting state' refers to a CISG contracting state who availed itself of the option of making an article 95 reservation and 'non-reservation state' or 'non-reservation contracting state' refers to a CISG contracting state that has not made an article 95 reservation.

The CISG Advisory Council is known by its acronym 'CISG AC'. In this contribution, the relevant Advisory Council Opinion analysed will be referred to as 'the AC Opinion' or merely 'the Opinion'.

The concepts lex causae (governing law or applicable law) and 'proper law of the contract' are used interchangeably and indicate the legal system that governs an international contract in whole or in part. ${ }^{16}$

\section{The CISG AC and its Work}

The CISG Advisory Council (CISG AC or the Council) is an academic initiative by the Institute of International Commercial Law at Pace University, New York and the Centre for Commercial law Studies, Queen Mary University, London. Renowned academics in the field of international commercial law (and widely recognised as experts in the CISG) were invited to become members of the Council. The Council was established in 2001 and the late Peter Schlechtriem was elected as the first chairperson of the Council. ${ }^{17}$ A list of the current Council Members can be obtained from the Council's website. ${ }^{18}$

The CISG AC's main goal is the promotion of uniform interpretation of the CISG and, to further this aim, the Council prepares and publishes interpretations of complex or controversial provisions of the CISG. Even though these interpretations do not count as 'official interpretations', they have been referred to by courts in contracting states and are held in high regard by other CISG commentators. ${ }^{19}$

15 This is the definition provided for the term 'reservation' in the Vienna Convention on the Law of Treaties (VCLT) 1969-05-23, Vienna 1155 UNTS 331; the CISG uses the term 'declaration' and the VCLT refers to the term 'reservation'. These terms are also employed interchangeably in the relevant CISG AC Opinion.

16 Forsyth Private International Law. The modern Roman-Dutch Law including the Jurisdiction of the High Courts (2012) 316-317.

17 Schlechtriem was the author and editor of several well-respected CISG commentaries in German and English, the most well-known English title is Commentary on the UN Convention on the International Sale of Goods (CISG), first published in 1986, with a second edition in 1998. The latest edition (2010) is edited by Ingeborg Schwenzer, who is also the current chair of the CISG AC.

18 See CISG Advisory Council 'Council Members’ 2016 available from http:// www.cisgac.com/council-members/ (accessed 2016-07-21).

19 See CISG Advisory Council 'Bibliography' 2016 available from http:// www.cisgac.com/bibliography-l (accessed 2016-07-21) for a select bibliography in this regard. 
The CISG AC has been granted observer status at the United Nations Commission on International Trade Law (UNCITRAL) ${ }^{20}$ as well as at the Governing Council of the International Institute for the Unification of Private Law (UNIDROIT). ${ }^{21}$

\section{CISG AC Opinion $15^{22}$}

This AC Opinion is aimed at a better understanding of articles 95 and 96 of the CISG. Both these articles fall under Part IV of the Convention, termed 'final provisions'. 23

In this contribution, the Opinion will only be analysed insofar as it addresses article 95. Article 96 of the Convention concerns a permissible reservation in respect of a completely unrelated matter and is not of relevance for the present discussion.

The AC Opinion consists of the official opinion or interpretation of articles 95 and 96 - also referred to as the black letter text - followed by comments that elucidate the Council's interpretation. The comments include an overview of the relevant article's drafting history, the scope of the reservation and the effects of the reservation.

The text of the Opinion concerning article 95 reads as follows:

1. A declaration under [a]rticle 95 excludes the declaring [c]ontracting [s]tate's obligation under public international law to apply the Convention in accordance with article 1(1)(b). However, it does not prevent the courts of such a [s]tate from applying the Convention when the rules of private international law lead to the application of the law of a [c]ontracting [s]tate.

2. A declaration under [a]rticle 95 is without any effect for the Convention's applicability in accordance with [a]rticle 1(1)(a). In applying [a]rticle 1(1)(a), it is irrelevant whether the forum [s] tate has made an [a]rticle 95 declaration or whether one (or both) parties to the sales contract have their place of business in a [s]tate which has made an [a]rticle 95 declaration.

3. When the forum is in a [c]ontracting [s]tate that has made no declaration under [a]rticle 95, the Convention applies in accordance with [a]rticle

20 UNCITRAL official website: www.uncitral.org (accessed 2015-07-20).

21 UNIDROIT official website: www.unidroit.org (accessed 2015-07-20).

22 The full text of this opinion may be accessed electronically on the CISG Advisory Council's website available from http://www.cisgac.com/cisgacopinion-no15/ (accessed 2016-07-21).

23 The final provisions of the CISG span from arts 89-101. These articles include diplomatic clauses, reservation clauses, clauses addressing temporal aspects of the Convention and clauses that explain the relationship of the CISG to other international instruments. For an overview and discussion of these provisions, see Schlechtriem, Schwenzer \& Hachem 'Final Provisions' in Schwenzer (ed) Schlechtriem and Schwenzer. Commentary on the UN Convention on the International Sale of Goods (CISG) (2010) 1170-1198. 
1(1)(b) even when the rules of private international law lead to the application of the law of a [c]ontracting state that has made an [a]rticle 95 declaration. 24

\section{The Advisory Council's Interpretation of the Effect of the Reservation for Courts in Reservation Contracting States}

Paragraph 1 of the AC's Opinion speaks to the effect of the reservation for courts in countries who have availed themselves of the option to exclude application of the CISG in terms of article 1(1)(b) when ratifying or acceding to the Convention.

The AC Opinion emphasises the fact that the reservation removes a reserving state's public international law obligation to apply the CISG under article 1(1)(b). ${ }^{25}$ Additionally, the Opinion states that a court in a reservation state is still free to choose to apply the Convention under circumstances as provided for in terms of article $1(1)(b){ }^{26}$ In other words, making an article 95 reservation relieves a reservation state from the obligation to apply the CISG if the requirements for its application under article 1(1)(b) are met, but does not prohibit a court in a contracting state from applying the CISG in terms of the last-mentioned provision if it so chooses. In this regard, the Opinion provides that a forum in a reservation state may elect to uphold a parties' direct choice of the CISG as governing law of their contract or the choice of a CISG contracting state. ${ }^{27}$ The rules relating to the validity of a choice of law clause form part of private international law and the forum would uphold such a choice in line with its principles of private international law. ${ }^{28}$ This view may possibly be disputed if the parties choose the law of a reservation contracting state as governing law of their contract. In such instances, it may be argued that the correct application of the proper law would require the domestic sales law of the chosen lex causae to be applied. $^{29}$

24 See text of the Opinion supra $\mathrm{n} 13$ at $\mathrm{p} 2$.

25 AC Opinion par 3.7.

26 Ibid. See also Schroeter 'Backbone or Backyard of the Convention? The CISG's Final Provisions' in Andersen \& Schroeter (eds) Sharing International Commercial Law across National Boundaries. Festchrift for Albert H Kritzer on the Occasion of his Eightieth Birthday (2008) 440 who states that a reserving state, although 'not obliged to do so under public international law, are still entitled to apply the Convention in cases in which the prerequisites of article 1(1)(a) CISG are not fulfilled'.

27 AC Opinion par 3.8.

28 Herre 'Final Provisions' in Kröll, Mistelis \& Viscasillas (eds) UN Convention on Contracts for the International Sale of Goods (CISG) Commentary (2011) 1210; Schwenzer \& Hachem 'Sphere of Application' in Schwenzer (ed) supra $\mathrm{n} 23$ at 104.

29 See par 72 below. 
It seems as though certain reservation states give a more extensive interpretation to the article 95 reservation than what was intended by the drafters of the CISG. The Opinion refers to the fact that Singapore - a reservation state - has included a section in its Sale of Goods (United Nations Convention) Act that categorically states that the CISG will only apply when both parties are from different CISG contracting states. ${ }^{30}$ Furthermore, at least three United States (US) decisions have been handed down indicating that US courts will only apply the CISG if both parties are from CISG contracting states. ${ }^{31}$

However, the Opinion makes it clear that the AC do not regard an article 95 reservation as having the effect that courts in reservation states should only apply the CISG if the requirements of article 1(1)(a) are met. $^{32}$ As the AC points out, this interpretation of an article 95 reservation cannot be deduced from the text of the Convention. ${ }^{33}$ This far-reaching interpretation of an article 95 reservation is also not supported by commentators. ${ }^{34}$

A matter not directly addressed by the AC Opinion, is the position where a forum in an article 95 reservation state is faced with an international sales contract dispute under circumstances where the requirements of article 1(1)(a) of the CISG are not met, the contract contains no choice of law clause, and the court assigns the law of a nonreservation contracting state as the proper law of the contract. Should the CISG be applied by the forum under these circumstances? ${ }^{35}$

Most authors advocate the application of the CISG in this scenario as part of the proper law of the contract. ${ }^{36}$ It has also been stated, in this regard, that the court may be said to have a duty to apply the CISG under

30 S 3(2) of the Singapore Sale of Goods (United Nations Convention) Act 14 of 1995. See AC Opinion par 3.9.

31 Impuls ID International SL, Impuls ID Systems Inc and PSIAR SA $v$ Psion Teklogix Inc (2002-11-22) available from http://cisgw3.law.pace.edu/cases/ 021122u1.html (accessed 2015-07-20); Prime Start Ltd v Maher Forest Products Ltd (2006-07-17) available from http://cisgw3.law.pace. edu/cases/06071 7u1.html (accessed 2016-07-21); Princess d'Isenbourg et Cie Ltd $v$ Kinder Caviar Inc (2011-02-22) available from http:/l cisgw3.law.pace.edu/cases/110222u1.html (accessed 2015-07-20). See Wethmar-Lemmer De Jure 2010 supra n 14 at 371 for a short synopsis of the first two decisions.

32 Opinion par 3.9.

33 Ibid.

34 Ferrari supra $\mathrm{n} 11$ at 87; Schroeter 'Backbone or Backyard of the Convention? The CISG's Final Provisions' in Andersen \& Schroeter (eds) supra $\mathrm{n} 26$ at 440.

35 See Wethmar-Lemmer De Jure 2010 supra n 14 at 374-376 for a discussion in this regard.

36 Herre 'Final Provisions' Kröll, Mistelis \& Viscasillas (eds) supra n 28 at 1210; Ferrari supra $\mathrm{n} 11$ at 88; Torsello 'Reservations to international uniform commercial law conventions' 2000 Revue de Droit Uniforme / Uniform Law Review 108; Kritzer, Vanto, Vanto \& Eiselen International Contract Manual (2008) 95-39; Schwenzer, Fountolakis \& Dimsey International Sales Law. A Guide to the CISG (2012) 10; Winship 'The Scope of the Vienna Convention 
these circumstances - 'derived not from the CISG, but from the forum's own choice of law rules'. ${ }^{37}$ In other words, correct application of the proper law of the contract, as determined by the private international law rules of the forum, requires that the CISG be applied.

However, it has been argued that:

a court in [a reservation state] might adopt the line of reasoning that since its own legislature has deprived it of the possibility of applying the Convention pursuant to article 1(1)(b), then it should only apply it when the requirements of article 1(1)(a) are met. ${ }^{38}$

According to this interpretation, the forum in the reservation state might consider itself not bound to apply the CISG via article 1(1)(b) under any circumstances. ${ }^{39}$

The present author agrees with the scholars who support the application of the CISG in this scenario. Since the requirements for application of the convention under article 1(1)(a) are not met, the forum will turn to its rules of private international law to determine the law applicable to the contract. If its private international law finds the law of a CISG contracting state applicable, it should apply the CISG as part of that legal system. In other words, correct application of the foreign law requires the forum to apply the CISG. This does not amount to application in terms of article 1(1)(b). ${ }^{40}$ According to this argument, the CISG is applied as part of the proper law, assuming that it has been ascertained by the forum that the CISG does indeed form part of the proper law. ${ }^{41}$ It is trite law that 'if we look at treaties from the municipal point of view ...

on International Sales Contracts' in Galston \& Smit (eds) International Sales: The United Nations Convention on Contracts for the International Sale of Goods (1984) 1-31;

37 Spagnolo CISG Exclusion and Legal Efficiency (2014) 13.

38 Evans 'Final Provisions' in Bianca \& Bonell Commentary on the International Sales Law. The 1980 Vienna Sales Convention (1987) 656. See also, Thieffry 'Sale of goods between French and US merchants: Choice of law considerations under the UN Convention on Contracts for the International Sale of Goods' 1988 International Lawyer 1018.

39 Bell 'Why Singapore should withdraw its reservation to the United Nations Convention on Contracts for the International sale of Goods (CISG)' 2005 SYBIL 65.

40 Fawcett, Harris \& Bridge International Sale of Goods in the Conflict of Laws (2005) 916-917, 979; Schroeter 'Backbone or Backyard of the Convention? The CISG's Final Provisions' in Andersen \& Schroeter (eds) supra n 26 at 441.

41 In this regard it would be relevant whether a monist or dualist approach is followed by the lex causae (for an excursus on monism and dualism, see Aust Modern Treaty Law and Practice (2007) 183-195). Should a dualist approach be followed, the CISG would only form part of the domestic law of the lex causae if the treaty has been transformed or adopted into domestic law by enacting the necessary legislation - see Dugard International Law: A South African Perspective (2005) 47. Parties to international treaties would be in breach of their treaty obligations if they did not give effect to the treaty by enacting, or, if necessary, amending their domestic legislation. However, it may not be always assumed that 'once a treaty has entered into 
such rules constitute binding national law'. ${ }^{42}$ Adopting this line of reasoning then, necessitates the conclusion that if the law of another reservation contracting state is found to be applicable, by virtue of the rules of private international law of the forum in a reservation state, then the proper law's domestic sales law and not the CISG should be applied by the forum. ${ }^{43}$

\section{Impact of the Reservation on the Status of 'Contracting State'}

The second paragraph of the AC Opinion emphasises the fact that an article 95 reservation has no impact upon the Convention's application in terms of article 1(1)(a). ${ }^{44}$ Making an article 95 reservation does not impact upon a state's status as a 'CISG Contracting state'. 45 This interpretation is also undisputed by the commentators. ${ }^{46}$

\section{The Advisory Council's Opinion in Respect of the Effect of the Reservation for Courts in Non-reservation Contracting States}

\section{Arguments in Favour of and Against Application of the CISG when a Forum in a Non-reservation Contracting State Finds the Law of a Reservation State Applicable}

The AC Opinion advocates application of the CISG in this scenario. ${ }^{47}$ According to this argument, the forum is bound to apply the CISG under article 1(1)(b) of the Convention if the requirements of its application under this provision are met. It is argued that a reservation state remains a CISG contracting state ${ }^{48}$ and the forum has an international law

force for a state, it is in force in that state; in other words, that it has become part of its law' (Aust 178). For the most part, states would comply with their international treaty obligations, but it may be prudent for the forum seized of the dispute to investigate whether the CISG indeed forms part of the domestic law of the lex causae before applying it on that ground.

42 Hambro 'The Relations between International Law and Conflict Law' Recueil des Cours. Collected Courses of the Hague Academy of International Law (1962) 15.

43 Spagnolo supra $\mathrm{n} 37$ at 14.

44 AC Opinion par 2.

45 AC Opinion par 3.11.

46 See, inter alia, Ferrari supra $n 11$ at 90; Herre 'Final Provisions' Kröll, Mistelis \& Viscasillas (eds) supra n 28 at 1211; Schwenzer \& Hachem 'Sphere of Application' in Schwenzer (ed) supra n 23 at 43.

47 AC Opinion par 3.14

48 Ibid. 
obligation to apply the CISG, since the forum is bound by article 1(1)(b). ${ }^{49}$ According to this view, proof of the fact that a state, which made a reservation under article 95 , remains a contracting state, is to be found in comparing the wording of article 95 with that of the other reservations under the CISG. ${ }^{50}$ The reservations make provision for the fact that all states, making a reservation under articles 92, 93 and 94 of the CISG, are deprived of their status as a contracting state for purposes of article 1(1) of the CISG. ${ }^{51}$ However, article 95 contains no comparable provision depriving a reservation state of its status as a contracting state for the purposes of article 1(1)(b). Therefore, when the law of an article 95 reservation is found to be applicable in terms of the rules of private international law of the forum, the conditions for application of the CISG under article 1(1)(b) are met from the perspective of the forum, and it is bound to apply the CISG. ${ }^{52}$ It has also been stated that an article 95 reservation made by one state cannot bind another state. ${ }^{53}$

The AC Opinion acknowledges that there are also a considerable amount of commentators who support the view that a forum in a nonreservation contracting state, whose rules of private international law point to the application of the law of a reservation state, should apply the domestic law of the proper law and not the CISG. ${ }^{54}$ According to the AC Opinion, the reasoning behind this view is that the forum should apply the proper law in the same manner as a forum in the proper law a state would have. ${ }^{55}$ A forum in the reservation state would not have applied the CISG under these circumstances and, therefore, the forum in the nonreservation state, whose rules of private international law direct it to the

49 Herre 'Final Provisions' Kröll, Mistelis \& Viscasillas (eds) supra n 28 at 1211; Huber 'Article 1' in Huber \& Mullis The CISG. A New Textbook for Students and Practitioners (2007) 4154 ;

50 AC Opinion par 3.14; Fawcett, Harris \& Bridge supra n 40 at 980.

51 See the text of these provisions as part of the CISG text.

52 AC Opinion par 3.14. This view is supported by Bell 2005 SYBIL supra $n 39$ at 63; Enderlein \& Maskow International Sales Law. United Nations Convention on Contracts for the International Sale of Goods. Convention on the Limitation Period in the International Sale of Goods (1992) 381; Ferrari 'Specific topics of the CISG in the light of judicial application and scholarly writing' 1995 Journal of Law and Commerce 46; Ferrari Contracts for the International sale of Goods (2012) 90; Schlechtriem, Schwenzer \& Hachem 'Final Provisions' in Schwenzer (ed) supra n 23 at 1191 (contra Schlechtriem's opinion in a previous edition of this work (reference in $n 55$ below); Torsello 2000 Uniform Law Review supra n 36 at 108.

53 Ferrari 1995 Journal of Law and Commerce 46.

54 AC Opinion par 3.16.

55 AC Opinion par 3.16. This argument is supported by Evans 'Final Provisions' in Bianca \& Bonell (eds) supra $\mathrm{n} 38$ at 657; Dore 'Choice of law under the International Sales Conventions: A US Perspective' 1983 American Journal of International Law 539; Schlechtriem 'Final Provisions' in Schlechtriem \& Schwenzer (eds) Commentary on the UN Convention on the International Sale of Goods (CISG) (2005) 933; and Winship 'Private international law and the UN Sales Convention' 1988 Cornell International Law Journal 525. 
application of the law of the reservation state, should also not apply the CISG. ${ }^{56}$ The AC Opinion disagrees with this argument by stating that:

The essential assumption underlying the opinion criticized here is that the forum's rules of private international law when applied under article 1(1)(b) CISG result in the application of the law of the state that the PIL rules refer to, of which the Convention forms a part. This assumption, it is submitted, is incorrect. The reason becomes evident when the wording of article 1(1)(b) CISG is read in its entirety, including its introductory phrase: 'This Convention $^{57}$ applies to contracts of sale of goods between parties whose places of business are in different states ... when the rules of private international law lead to the application of the law of a contracting state'. It is therefore 'this Convention' which the judge in a contracting state has to apply when its forum's rules of private international law lead to the application of the law of a contracting state, and not 'the law of a contracting state' (that may or may not have made a declaration under article 95). The contrary opinion instead reads the partial phrase 'lead to the application of the law of a contracting state' as calling for the application of that state's law, thereby confusing cause and effect under article 1(1)(b). It should therefore not be followed. 58

The AC Opinion's view accords with that of commentators who contend that under these circumstances, the forum should apply the CISG under article 1(1)(b) as part of the law of the forum and not as part of the law of the reservation state. ${ }^{59}$

It deserves mention that two very well-respected CISG commentators advocated for the application of domestic sales law under these circumstances. Honnold argued for non-application of the CISG under these circumstances based on policy considerations. ${ }^{60} \mathrm{He}$ argued that the US made the reservation 'to protect its traders from being deprived of their familiar domestic law without the countervailing gain of supplanting the foreign law, ${ }^{, 61}$ and the CISG, therefore, should not be applied in the situation above. Schlechtriem motivated non-application of the Convention by arguing that article 7(1) of the CISG requires the promotion of uniformity of application of the Convention and that

56 Ibid.

57 Emphasis added by the AC.

58 AC Opinion par 3.16 (14). See also Schroeter 'Backbone or Backyard of the Convention? The CISG's Final Provisions' in Andersen \& Schroeter (eds) supra $\mathrm{n} 26$ at 447 where this argument is echoed.

59 Fawcett, Harris \& Bridge supra n 40 at 981; see also Zeller CISG and Unification of International Trade Law (2007) 40, who states that it is difficult to imagine that a forum situated in a non-reservation contracting state, whose conflict of laws rules point to the application of the law of a reservation state and who could apply the CISG as part of their own legal principles under article 1(1)(b), would elect to apply the domestic law of the reservation state instead.

60 Honnold Uniform Law for International Sales under the 1980 United Nations Convention (1991) 41.

61 Ibid; see Bell's (2005 SYBIL supra n 39 at 64) remark in this regard. 
disregarding the article 95 reservation, when applying the law of a reservation state, would negate this directive. ${ }^{62}$

It is submitted that Bernasconi offers the most compelling argument against application of the CISG under these circumstances. He states that the lex causae (which is the law of the reservation state) 'has not enacted the CISG for cases similar to this one, thus the Convention's rules are inapplicable. By refusing to consider the reservation filed under article 95 , the forum judge would fail to recogni[s]e the lex causae altogether' ${ }^{63}$

\section{Correct Application of a Foreign Lex Causae or Proper Law}

There is much support for the view that application of the CISG, under article 1(1)(b), amounts to application of the Convention as part of the proper law of the contract - assuming of course that the lex causae is that of a CISG contracting state. It has also been established that a state that made an article 95 reservation, remains a contracting state under the CISG. ${ }^{64}$

It is widely accepted that the lex causae should be applied in the same manner as a forum, in its state of origin, would have applied it. ${ }^{65}$

A renowned conflicts scholar explained the correct application of a foreign lex causae as follows:

In an autonomous conflict system the notion of "origin-conform application" of foreign law is not an expression of loyalty towards the State of origin of a foreign law. Instead it is primarily a consequence of taking seriously the command of the national rules on choice of law, and truly subjecting the dispute to the "really applicable" foreign law. The principle of origin-conform application of foreign law aims at safeguarding that foreign law in another State's court [and requires that it] is applied in the same manner as a court (or other competent authority) would do in the State of origin of that law. The perspective to be chosen is, in other words, that of the foreign court. ${ }^{66}$

As applied to the topic at hand, the CISG can only find application as part of the legal system indicated by the rules of private international law of the forum, if the applicable lex causae would designate the CISG as the relevant body of rules to be applied in the circumstances. The same holds true for application of the CISG as part of a proper law chosen by the parties.

62 Schlechtriem 'Article 1' in Schlechtriem \& Schwenzer supra $\mathrm{n} 55$ at 37.

63 Bernasconi 'The personal and territorial scope of the Vienna Convention on Contracts for the International Sale of Goods (article 1)' 1999 NILR 168.

64 See par 6 above.

65 Jänterä-Jareborg 'Foreign Law in National Courts: A Comparative Perspective' Recueil des Cours. Collected Courses of the Hague Academy of International Law (2003) 230.

66 Idem 230-231. See also Bogdan 'Private International Law as a Concept of the Law of the Forum' Recueil des Cours. Collected Courses of the Hague Academy of International Law (2010) 112. 


\section{International Law Obligation versus Correct Application of the Lex Causae}

Although the present author supports a pro convention approach in general, it is difficult to ignore the arguments related to the correct application of the lex causae. Indeed, a forum in a non-reservation contracting state is bound by article 1(1)(b) and this provision is in force in the forum state. ${ }^{67}$ However, article 1(1)(b) directs the CISG to be applied if the rules of private international law (of the forum) refer to the law of a contracting state qua lex causae. ${ }^{68}$ In other words, in terms of the forum state's rules of private international law, the law of the reservation state has been designated as the applicable law to the dispute at hand. Going forward from this point on, the forum, therefore, is not applying its own law (that article 1(1)(b) forms part of) to the international sales contract, but the proper law of the contract.

Therefore, the most critical question is which rules of the lex causae are to be applied? The rules that the lex causae ordains for international sales contracts under these circumstances. Since the requirements for application of the CISG are not met from the perspective of the lex causae, correct application of the lex causae requires domestic sales law to be applied by the forum.

However, from the perspective of the forum, requirements for application of the CISG are met in terms of article 1(1)(b), since it is clear that a reservation state remains a CISG contracting state. The forum state therefore has an international law obligation to apply the CISG.

There seems to be an insoluble disconnect between the correct application of the lex causae from a private international law perspective on the one hand, and the forum state's international law obligation to apply the CISG on the other.

There may, however, be an alternative argument that could solve this conundrum - a recent argument supported by several contemporary CISG commentators and based on a 'literal reading' of article 1(1)(b). ${ }^{69}$ According to this argument, article 1(1)(b) only requires reference to the rules of private international law of the forum to determine whether the CISG applies per se, but does not rely on the rules of private international law to determine the extent to which the CISG should be applied. ${ }^{70}$ The rules of private international law, thus, only serve as a 'trigger' for the application of the CISG, but article 1(1)(b) 'remains the controlling provision' for the sphere of application for forums situated in non-

67 Hambro supra $\mathrm{n} 42$ at 15, Thirlway 'Concepts, Principles, Rules and Analogies: International and Municipal Legal Reasoning’ Recueil des Cours. Collected Courses of the Hague Academy of International Law (2002) 321.

68 It is the only acceptable reading of this provision; see Wethmar-Lemmer 2008 De Jure supra $n 3$ at 419.

69 Spagnolo supra $\mathrm{n} 37$ at 16.

70 Ibid. 
reservation contracting states. ${ }^{71}$ One then regards article 1 (1)(b) as requiring the CISG to be applied 'ipso iure' by non-reservation contracting states. ${ }^{72}$ This is also the view that the CISG AC promotes in their Opinion. ${ }^{73}$ The most convincing argument in support of this interpretation of article 1(1)(b) is forwarded by Spagnolo, who states that the inclusion of article 1(1)(b) would otherwise have been redundant the forum's choice of law rules would have applied in any event. ${ }^{74}$

Another explanation of this literal interpretation of article 1(1)(b) is to regard the application of the CISG under this scenario as being applied as part of the forum state's internal law. ${ }^{75}$ According to this argument, the CISG is not being applied as part of the lex causae, and is therefore not foreign law that needs to be proved. ${ }^{76}$

\section{The Advisory Council's View of the Effect of the Reservation for Courts in Non-contracting States Faced with the (Potential) Application of the CISG}

The Opinion emphasises the fact that a forum in a non-contracting state is under no obligation to refer to the CISG directly. ${ }^{77}$ A court, in a noncontracting state, will be faced with possibly applying the CISG when its rules of private international law point to the law of a contracting state as lex causae. If the lex causae is that of a CISG contracting state that made an article 95 reservation, and the requirements for application of the CISG under article 1(1)(a) are not met, the AC Opinion states that the court would most probably apply the domestic law of the lex causae since a forum of the lex causae would have also applied its domestic law under these circumstances. ${ }^{78}$

Application or negation of the CISG rests on the question of whether the CISG could be seen as part of the applicable law in this scenario? Most authors support non-application of the CISG under these circumstances due to the fact that the requirements for application under article 1(1)(a)

71 Spagnolo supra $\mathrm{n} 37$ at 17.

72 Ibid

73 AC Opinion par 3.16.

74 Spagnolo supra $\mathrm{n} 37$ at 18.

75 Bridge The International Sale of Goods (2013) 477. See also Fawcett, Harris $\&$ Bridge supra $\mathrm{n} 40$ at 980 where they state that, under these circumstances, the forum applies the CISG under article 1(1)(b) as part of the law of the forum, and not as part of the law of the reservation state.

76 Ibid.

77 AC Opinion par 3.18.

78 Ibid. 
are not met and application under article 1(1)(b) was excluded by the proper law state. ${ }^{79}$

That being said, there are authors who support the application of the CISG in this scenario. According to their argument, an article 95 reservation state still remains a CISG contracting state and the CISG should be applied by virtue of it being part of the law of a CISG contracting state. ${ }^{80}$ The present author supported application of the CISG under these circumstances in an earlier contribution. ${ }^{81}$ Subsequently, the present author has been convinced that the argument against application of the CISG is stronger here. There could be no other ground for applying the CISG under these circumstances than as part of the proper law of the contract. From the perspective of the lex causae, the CISG is not the relevant body of law to be applied. Article 1(1)(b) also does not form part of the law of the forum, since the forum is situated in a noncontracting state. Application of the CISG, therefore, would not constitute correct application of the proper law. ${ }^{82}$

\section{Diagram}

\section{Summary of Permutations Under Article 95 Of The CISG}

Note: Assume that the requirements for application of the CISG under article 1(1)(a) are not met.

\begin{tabular}{|l|l|l|}
\hline Forum & $\begin{array}{l}\text { Applicable Legal } \\
\text { System }\end{array}$ & CISG Applicable? \\
\hline $\begin{array}{l}\text { In reservation } \\
\text { contracting } \\
\text { state }\end{array}$ & $\begin{array}{l}\text { Law of reservation } \\
\text { contracting state }\end{array}$ & NO \\
\hline $\begin{array}{l}\text { In reservation } \\
\text { contracting state }\end{array}$ & $\begin{array}{l}\text { Law of non-reservation } \\
\text { contracting state }\end{array}$ & YES \\
\hline
\end{tabular}

79 Dore 1983 American Journal of International Law supra n 55 at 538, Schlechtriem 'Commentary on Oberlandesgericht Düsseldorf 2 July 1993' in International Contract Manual: Guide to the UN Convention (1994) available from http://cisgw3.law.pace.edu/cases/930702g1.html (accessed 2015-08-04), Spagnolo supra 37 at 19, Winship 1988 Cornell International Law Journal supra $\mathrm{n} 55$ at 525.

80 Ferrari 1995 Journal of Law and Commerce supra $n 52$ at 48; Torsello 2000 Uniform Law Review supra n 36 at 109, Wethmar-Lemmer 2010 De Jure supra $\mathrm{n} 14$ at 378.

81 Wethmar-Lemmer 2010 De Jure supra n 14 at 378.

82 Wethmar-Lemmer The Vienna Sales Convention and Private International Law (2015) 216. 


\begin{tabular}{|l|l|l|}
\hline $\begin{array}{l}\text { In non-reservation } \\
\text { contracting state }\end{array}$ & $\begin{array}{l}\text { Law of reservation } \\
\text { contracting state }\end{array}$ & $\begin{array}{l}\text { YES - forum state has } \\
\text { international law } \\
\text { obligation to apply the } \\
\text { CISG, } \\
\text { or } \\
\text { NO - applying the CISG } \\
\text { does not constitute } \\
\text { correct application of the } \\
\text { lex causae }\end{array}$ \\
\hline In non-contracting state & $\begin{array}{l}\text { Law of reservation } \\
\text { contracting state }\end{array}$ & NO \\
\hline
\end{tabular}

\section{Conclusion}

Courts of certain article 95 reservation states seem to conclude that they should only apply the CISG if the requirements for application under article 1(1)(a) are met. The AC Opinion stresses the fact that the article 95 reservation relieves reservation states from the public international law obligation to apply the CISG under article 1(1)(b), but does not prohibit them from applying it should they wish to do so. The overwhelming majority of commentators also support the view that fora in reservation states should apply the CISG if the law of a non-reservation contracting state is found to be applicable as the proper law of the contract. Staying true to the principle of origin-conform application of the lex causae would indeed require the CISG to be applied as the relevant body of rules designated for international sales contracts under the lex causae. If this argument is followed through, then the CISG should not be applied if a forum in a non-reservation contracting state finds the law of a reservation state applicable in terms of its rules of private international law. However, the CISG AC supports application of the CISG in the lastmentioned scenario, based on the view that the Convention's applicability criteria are met from the forum's perspective. This argument is certainly commendable from a uniform law perspective and has won the support of several authors but does not, unfortunately, enjoy unanimous acceptance.

The purpose of the CISG is the adoption of uniform rules for international trade in order to contribute to the removal of trade barriers and to promote the development of international trade. ${ }^{83}$ It seems as though the object and purpose of the CISG requires it to be applied as widely as possible. Therefore, the CISG AC's interpretation of the article 95 reservation, in a manner that ensures minimum impact on the Convention's scope of application, is certainly to be supported.

83 See the Preamble to the CISG. 